\title{
Kierunki zmian w prawie o bezpieczeństwie morskim
}

\section{Wprowadzenie}

Obecnie obowiązująca ustawa o bezpieczeństwie morskim weszła w życie w 2011 r. ${ }^{1}$ Potrzeba jej nowelizacji postulowana była przez przedstawicieli doktryny od początku jej funkcjonowania². Warto zaznaczyć, że na uregulowanie materii bezpieczeństwa morskiego $\mathrm{w}$ akcie rangi ustawowej trzeba było w Polsce czekać kilkadziesiąt lat. W okresie międzywojennym przyjęto w Polsce kilka ustaw dotyczących problematyki morskiej. Kwestia bezpieczeństwa morskiego uregulowana została po raz pierwszy w akcie rangi ustawowej w Rozporządzeniu Prezydenta RP z dnia 24 listopada 1930 r. o bezpieczeństwie statków morskich ${ }^{3}$. Rozporządzenie to stanowiło fragment pakietu legislacyjnego mającego doprowadzić do odbudowania morskiej tożsamości Polski oraz umocnienia więzi administracyjnych Wybrzeża z Polską. Ze względu na przyjęcie takich właśnie celów morska legislacja międzywojenna odnosiła się głównie do kwestii wzmocnienia administracji morskiej ${ }^{4}$. W okresie powojennym, przez cały okres trwania Polski Ludowej nie przyjęto spójnej regulacji dotyczącej bezpieczeństwa morskiego.

1 Tekst jedn. Dz.U. 2016, poz. 281.

2 Zob. M. Koziński, Ustawa o bezpieczeństwie morskim, stan de lege lata i postulaty de lege ferenda, "Prawo Morskie” 2012, t. XXVIII, s. 51 i n.

3 Tekst jedn. Dz.U. 1938 Nr 46, poz. 376.

${ }^{4}$ Kwestie prywatnoprawne związane z żeglugą uregulowane były Ustawą z dnia 1 VIII 1919 r. utrzymującą w mocy ustawodawstwo niemieckie na obszarach byłego zaboru pruskiego (Dz.Pr.P.P. 1919 Nr 64, poz. 385). 
Tematyka ta była regulowana aktami wykonawczymi organów administracji morskiej ${ }^{5}$. Liczba owych aktów oraz ich zakres niewątpliwie wprowadzały pewien niepożądany stan, a potrzeba opracowania spójnej ustawy, bardziej kompleksowo obejmującej materię bezpieczeństwa, artykułowana była w doktrynie coraz silniej.

W efekcie koncepcji przyjętej w ramach Komisji Kodyfikacyjnej Prawa Morskiego pracujaccej w latach 1987-1997 kodeks morski stanowić miał regulację o charakterze prywatnoprawnym. Zagadnienia publicznoprawne zaś, uporządkowane wedle kryterium przedmiotowego, uregulowane zostały w kilku ustawach ${ }^{6}$. W efekcie wspomnianych założeń także materia dotycząca bezpieczeństwa morskiego została uregulowana w $2000 \mathrm{r}$. w pierwszej w powojennej Polsce ustawie o bezpieczeństwie morskim ${ }^{7}$. Akt ten systematyzował dotyczące owej dziedziny przepisy rozsiane wcześniej w licznych rozporządzeniach oraz Kodeksie morskim z 1961 r. ${ }^{8}$ W roku 2001 przyjęto nowy Kodeks morski, obowiązujący do dnia dzisiejszego. Przeniesienie przepisów dotyczących standardów bezpieczeństwa żeglugi do nowej ustawy zmieniło także, jak wspomniano wyżej, charakter Kodeksu morskiego. Nowy kodeks pozbawiony został właściwie przepisów o charakterze publicznoprawnym, a zasadniczym przedmiotem jego regulacji stało się cywilne prawo morskie.

Celem artykułu jest analiza zmian wprowadzonych przez polskiego ustawodawcę do ustawy o bezpieczeństwie morskim oraz próba określenia trendów regulacyjnych w tym zakresie. Polska legislacja dotycząca bezpieczeństwa morskiego musi pozostawać zgodna z regulacjami przyjmowanymi przez Międzynarodową Organizację Morską (dalej: IMO) oraz mającymi charakter regionalny regulacjami tworzonymi przez Unię Europejską (UE), której legislacja morska jest coraz bardziej kompleksowa ${ }^{9}$.

\footnotetext{
${ }^{5}$ Zob. M. Koziński, op. cit., s. 53 i n.
}

${ }^{6}$ Szerzej: M. Dragun Gertner, Polskie ustawodawstwo morskie a prawo międzynarodowe, „Studia Iuridica Toruniensia” 2002, t. II: Przemiany polskiego prawa, pod red. E. Kustry, s. 133.

${ }^{7}$ Ustawa z dnia 9 XI 2000 r. o bezpieczeństwie morskim (tekst jedn. Dz.U. 2006 Nr 99, poz. 693), dalej „u.b.m.”, „ustawa o bezpieczeństwie morskim”.

8 Trzon ustawy tworzyły przepisy dotyczące bezpieczeństwa morskiego zawarte wcześniej w Kodeksie morskim z 1961 r., do których dołączono także inne przepisy odnoszące się do bezpieczeństwa statku i ładunku, bezpiecznego uprawiania żeglugi oraz ratowania życia na morzu.

${ }^{9}$ Zob. np. M. Dragun Gertner, Wptyw prawa europejskiego na kodeks morski, "Zeszyty Naukowe Wyższej Szkoły Administracji i Biznesu" 2016, z. 23, s. 60 i n. 


\section{Pojęcie bezpieczeństwa morskiego}

Bezpieczeństwo morskie rozumiane jest jako bezpieczeństwo działalności ludzkiej na morzu (ang. maritime safety). Pojęcie to tradycyjnie obejmowało regulacje mające na celu minimalizowanie zagrożeń wynikających z charakteru samego morza jako żywiołu oraz z działalności użytkowników morza. Skupiało się ono zatem początkowo jedynie na zwiększeniu bezpieczeństwa życia ludzkiego oraz zmniejszeniu ryzyka związanego z utratą statku czy ładunku i dotyczyło aspektów nawigacyjnych i technicznych mających na celu ograniczanie i minimalizowanie klasycznych niebezpieczeństw morza. Innymi słowy, normy prawne dotyczące bezpieczeństwa morskiego regulowały początkowo jedynie kwestie związane $\mathrm{z}$ bezpieczeństwem statku morskiego $\mathrm{w}$ znaczeniu technicznym i jego zdatnością do żeglugi, bezpieczeństwem nautycznym, właściwą obsadą załogową oraz ratownictwem morskim. Regulacje te, poza normami dotyczącymi ratownictwa morskiego, miały charakter prewencyjny. $\mathrm{W}$ ostatnich dwóch, trzech dekadach zauważalny jest w unormowaniach międzynarodowych trend do rozszerzania pojęcia bezpieczeństwa morskiego o kwestie związane z ochroną środowiska morskiego (tzw. bezpieczeństwo ekologiczne), zapobieganie naruszeniom prawa na morzu oraz kwestie organizacyjne i zarządcze związane ze stanowieniem standardów dotyczących bezpiecznego zarządzania, kwalifikacji marynarzy oraz personelu lądowego zajmującego się eksploatacją urządzeń morskich.

O ile morskie prawo prywatne ma wielowiekową tradycję, a jego rozwój był bardzo stabilny, ewolucyjny ${ }^{10}$, o tyle publicznoprawne aspekty bezpieczeństwa morskiego zaczęły podlegać regulacjom prawnym dopiero w $X X$ w. Co prawda, istniały wcześniej pewne regulacje krajowe stanowiące przepisy dotyczące bezpieczeństwa statku oraz zapobiegania zderzeniom na morzu, jednak brak było całościowych regulacji w tym zakresie. Dopiero słynna katastrofa liniowca Titanic w 1912 r. zwróciła uwagę społeczności międzynarodowej na problem braku międzynarodowych wymagań dotyczących bezpieczeństwa morskiego w sytuacji, gdy rozwój technologiczny umożliwiał niesienie pomocy ${ }^{11}$.

${ }^{10}$ Pierwsze regulacje mające na celu rozłożenie ryzyka finansowego podróży morskiej sięgają starożytności - należy do nich np. słynna instytucja awarii wspólnej, spisana w Lex Rhodia de iactu ponad 2500 lat temu. Zob. np. J. Lopuski, Proces kształtowania się prawa morskiego, w: Prawo morskie, pod red. J. Lopuskiego, s. 59 i n.

${ }^{11}$ Charakterystyczne dla rozwoju bezpieczeństwa morskiego jest to, że jego ramy wyznaczane są właśnie poprzez rozwój technologiczny. Innymi słowy, regulacje podążają 
Prawo bezpieczeństwa morskiego można, w pewnym uproszczeniu, podzielić obecnie na bezpieczeństwo ludzi i statku od zagrożeń morza jako żywiołu i bezpieczeństwo środowiska od zagrożeń pochodzących ze statku (ang. maritime safety) oraz bezpieczeństwo w zakresie ochrony i przeciwdziałania czynom niedozwolonym na morzu, takim jak piractwo czy terroryzm morski (ang. maritime security) ${ }^{12}$. Filozofia obu tych działów bezpieczeństwa jest odmienna, co stało się jedną z przesłanek uregulowania w Polsce obu aspektów bezpieczeństwa morskiego w odrębnych ustawach. Ustawa o bezpieczeństwie morskim dotyczy zakresu maritime safety, zaś ochrona statku i portu przed czynami niedozwolonymi (maritime security) uregulowana jest w Ustawie z dnia 4 września 2008 r. o ochronie żeglugi i portów morskich ${ }^{13}$. Jednocześnie coraz bardziej zauważalne jest wprowadzanie regulacji procedur dotyczących tzw. czynnika ludzkiego, odnoszących się do postępowania na statku i w portach, mających poprzez stosunkowo szczegółowe unormowania zmniejszać ryzyko błędu ludzkiego ${ }^{14}$.

za możliwościami niesienia pomocy, ale także za nowymi rodzajami zagrożeń dla środowiska morskiego powodowanymi ze statków lub przez statki. Obecnie kwestie bezpieczeństwa morskiego uregulowane są w licznych konwencjach międzynarodowych, z których najważniejsze to: Międzynarodowa konwencja o bezpieczeństwie życia na morzu podpisana w Londynie 1 XI 1974 r. (Dz.U. 1984 Nr 61, poz. 318), dalej "SOLAS”, międzynarodowa konwencja o liniach ładunkowych podpisana w Londynie 5 IV 1966 r., konwencja w sprawie międzynarodowych przepisów o zapobieganiu zderzeniom na morzu podpisana w Londynie 20 X 1972 r., międzynarodowa konwencja o bezpiecznych kontenerach podpisana w Genewie 2 XII 1972 r., międzynarodowa konwencja o wymaganiach w zakresie wyszkolenia marynarzy, wydawania im świadectw oraz pełnienia wacht podpisana w Londynie 7 VII 1978 r. (dalej "STCW”), międzynarodowa konwencja o poszukiwaniu i ratownictwie morskim podpisana w Hamburgu 24 IV 1979 r., konwencja w sprawie przeciwdziałania czynom przeciwko bezpieczeństwu żeglugi podpisana w Rzymie 10 III 1988 r., konwencja o pracy na morzu. Coraz częściej także ochrona środowiska morskiego włączana jest do prawa bezpieczeństwa morskiego i określana jako bezpieczeństwo ekologiczne.

${ }^{12} \mathrm{O}$ rozróżnieniu pojęć martime safety i martime security zob.: J. Nawrot, O potrzebie wyraźnego rozróżniania pojęć "bezpieczeństwo" $i$ "ochrona” w prawie polskim. Uwagi na tle polskiej legislacji morskiej, "Prawo i Więźz" 2015, nr 4(14), s. 7; W. Adamczak, J. Nawrot, Bezpieczeństwo morskie - uwagi na tle anglosaskiego rozróżnienia maritime safety i maritime security, "Gdańskie Studia Prawnicze" 2015, t. XXXIII, s. 19 i n.

${ }^{13}$ Dz.U. Nr 171, poz. 1055.

${ }^{14}$ Przykładem takich regulacji jest Kodeks Bezpiecznego Zarządzania i Eksploatacją Statków (dalej „kodeks ISM”), będący częścią konwencji SOLAS. 


\section{Zakres przedmiotowy ustawy o bezpieczeństwie morskim}

W ustawie z 2000 r. porządkującej materię związaną z bezpieczeństwem morskim przyjęto systematykę wewnętrzną zbliżoną do konwencji o bezpieczeństwie życia na morzu (SOLAS) z uwzględnieniem postanowień najważniejszych konwencji z zakresu bezpieczeństwa morskiego, których Polska jest stroną ${ }^{15}$. W efekcie kręgosłupem ustawy były rozdziały 2-5 regulujące kolejno kwestie: budowy statku, jego stałych urządzeń i wyposażenia; kwalifikacji i składu załogi statku; bezpiecznego uprawiania żeglugi; ratowania życia na morzu. Ustawa inkorporowała postanowienia konwencji, których Polska jest stroną, uzupełniając je o delegacje dla właściwego ministra i dyrektorów urzędów morskich.

Stosunkowo szybko jednak okazało się, że ustawa ta wymaga zmian. Najbardziej naglącą przyczyną podjęcia prac nad nową ustawą była konieczność implementacji przez Polskę licznych aktów prawa Unii Europejskiej. Unijna legislacja morska z zakresu bezpieczeństwa morskiego zaczęła rozwijać się dynamicznie właściwie tuż po przyjęciu przez Polskę nowej ustawy z 2000 r. Powodem owej nowej aktywności Unii Europejskiej była seria katastrof zapoczątkowana w 1999 r. przez zatonięcie tankowca Erika.

Podjęte prace zostały zakończone przyjęciem nowej ustawy o bezpieczeństwie morskim w 2011 r. Ustawa ta jest zdecydowanie bardziej obszerna od poprzednio obowiązującej, choć jej wewnętrzna systematyka bazuje na wcześniej przyjętych rozwiązaniach. Ostatnia nowelizacja z 2015 r. $^{16}$ jest jednak zdecydowanie najobszerniejsza i zasługuje na omówienie.

\section{Ustawa nowelizująca}

Głównym celem opracowania noweli ustawy o bezpieczeństwie morskim z 2011 r. było wdrożenie do polskiego porządku prawnego dyrektyw unijnych: 2012/35/UE dotyczącej zmiany dyrektywy 2008/106/WE w sprawie minimalnego poziomu wyszkolenia marynarzy ${ }^{17} ; 2013 / 38 /$ UE

\footnotetext{
${ }^{15}$ Zob. przypis 11 .

${ }^{16}$ Ustawa z dnia 24 VII 2015 r. o zmianie ustawy o bezpieczeństwie morskim oraz niektórych innych ustaw (Dz.U. poz. 1320).

${ }^{17}$ Dz.Urz. UE L 343 z 14 XII 2012 r., s. 78.
} 
zmieniającej dyrektywę 2009/16/WE w sprawie kontroli przeprowadzanej przez państwo portu' ${ }^{18}$; 2014/111/UE zmieniającej dyrektywę 2009/15/WE w związku z przyjęciem przez Międzynarodową Organizację Morską (IMO) określonych kodeksów i powiązanych zmian do niektórych konwencji i protokołów ${ }^{19}$. Nowelizacja ma na celu także wprowadzenie zmian przepisów, których stosowanie od momentu wejścia w życie ustawy z $2011 \mathrm{r}$. stwarzało problemy w praktyce. Zmiany te zasadniczo dotyczą funkcjonowania inspekcji państwa bandery oraz Centralnej Morskiej Komisji Egzaminacyjnej.

\subsection{Zmiany w zakresie stosowania ustawy o bezpieczeństwie morskim}

Ważną zmianą zakresu przedmiotowego znowelizowanej ustawy jest nowa redakcja art. 3 doprecyzowująca zakres stosowania tego aktu w stosunku do statków o obcej przynależności państwowej. Ustawa zasadniczo ma zastosowanie do statków morskich o polskiej przynależności i statków obcych w zakresie w niej ustalonym. Wcześniej obowiązujące brzmienie rodziło wątpliwości interpretacyjne dotyczące zastosowania do obcych statków będących na polskich wodach wewnętrznych lub morzu terytorialnym przepisów wykonawczych dotyczących bezpiecznego uprawiania żeglugi i wyposażenia statków. Przepis ten nie był precyzyjny, a kwestia zakresu przedmiotowego ustawy wymaga, co jest oczywiste, regulacji $\mathrm{w}$ treści samego aktu. Zgodnie $\mathrm{z}$ nowym brzmieniem do statków obcych zastosowanie mają przepisy ustawy dotyczące inspekcji państwa portu oraz bezpiecznego uprawiania żeglugi ( $\mathrm{z}$ wyjątkiem art. 86 ust. 3 u.b.m.) z uwzględnieniem wiążących Polskę umów międzynarodowych.

Istotną zmianą jest także ta dotycząca włączenia do zakresu stosowania ustawy stałych platform wiertniczych. Jest to ważna i potrzebna poprawka, ponieważ eksploatacja polskich obszarów morskich przy użyciu platform wiertniczych na pewno będzie się intensyfikować. Polski prawodawca i tak późno dostosowuje prawo do rzeczywistych zmian w tym zakresie. Dotychczas ustawa o bezpieczeństwie morskim odnosiła się jedynie do ruchomych platform wiertniczych poprzez wskazanie w art. 5 u.b.m., że pojęciem "statek" objęte są również

\footnotetext{
${ }^{18}$ Dz.Urz. UE L 218 z 14 VIII 2013 r., s. 1.

${ }^{19}$ Dz.Urz. UE L 366 z 20 XII 2014 r., s. 83.
} 
ruchome platformy wiertnicze, chyba że powołane w ustawie umowy międzynarodowe stanowią inaczej. Kwestie związane z eksploatacją offshorowych urządzeń wiertniczych w polskim prawodawstwie rozproszone są $w$ licznych aktach prawnych. Podstawowe znaczenie dla ustalenia zasad tejże eksploatacji ma podział platform i urządzeń wiertniczych według kryterium ich statusu, tzn. tego, czy są one statkami czy nie. Jeśli są one w trakcie przemieszczania się, są uznawane za statek, co pozwala rozciągnąć na nie wszystkie krajowe przepisy dotyczące statków, w tym także odnoszące się do odpowiedzialności za zanieczyszczenia ze statków. W konsekwencji przyjęcia wyżej wskazanej perspektywy podziału platform na stałe i ruchome, liczne wątpliwości budzi jednak status platform stałych. Objęcie ich pewnym zakresem przepisów ustawy o bezpieczeństwie morskim należy uznać za odpowiadające wymogom polskich interesów gospodarczych i stanowiące pierwszy krok do bardziej kompleksowej regulacji ich statusu w polskim prawie.

Wprowadzone do ustawy o bezpieczeństwie morskim zmiany nie likwidują wszystkich wątpliwości związanych ze statusem platform wiertniczych lub wydobywczych, dlatego zasadne wydaje się dalsze rozszerzenie zakresu stosowania zasad bezpieczeństwa morskiego do stałych platform wiertniczych. Skoro bowiem w zakresie procedur ewakuacji, środków ratunkowych i ratowniczych, sygnałowych i łączności oraz kompetencji załóg ruchomych platform polski prawodawca nakazuje od dawna stosowanie zasad bezpieczeństwa morskiego tak jak na statkach, to biorąc pod uwagę, że w praktyce nie ma żadnych różnic $\mathrm{w}$ zakresie wspomnianych procedur na stałych i ruchomych platformach, zasadne wydaje się rozszerzenie ich stosowania na stałe platformy wiertnicze. Należy wobec tego rozważyć, czy Polska nie powinna przyjać bardziej kompleksowego rozwiązania kwestii stałych platform wiertniczych. Zagadnienie to jest tym bardziej zasadne, że państwo polskie zobowiązane było do implementacji do lipca 2015 r. dyrektywy 2013/30/UE w sprawie bezpieczeństwa działalności związanej ze złożami ropy naftowej i gazu ziemnego na obszarach morskich oraz zmiany dyrektywy 2004/35/WE ${ }^{20}$.

${ }^{20}$ Dz.Urz. UE L 178 z 28 VI 2013 r., s. 66. Wprowadzone do ustawy o bezpieczeństwie morskim zmiany dotyczące stałych platform wiertniczych nie rozwiązują problemu rejestracji takich platform oraz kwestii współpracy ministra właściwego do spraw gospodarki morskiej i ministra właściwego do spraw budownictwa. Kwestie zasad rejestracji urządzeń offshorowych zostaną zapewne uregulowane w przepisach Kodeksu 
Także kwestie nadzoru nad wspomnianymi urządzeniami wymagają bardziej kompleksowego uregulowania. Nowelizacja ustawy o bezpieczeństwie morskim nie zmieniła istniejącej w tym zakresie dychotomii. Nadal organem instytucjonalnym pełniącym nadzór nad stałymi platformami wiertniczymi w czasie, gdy prowadzą one prace eksploatacyjne, jest Okręgowy Urząd Górniczy w Poznaniu, a gdy przemieszczają się po polskich obszarach morskich, właściwy dyrektor urzędu morskiego (obecnie, ze względu na lokalizację platform na Bałtyku, jest to dyrektor Urzędu Morskiego w Gdyni). Zmiana w zakresie nadzoru powinna być jednak dokonana w Ustawie z dnia 21 marca 1991 r. o obszarach morskich Rzeczypospolitej Polskiej i administracji morskiej ${ }^{21}$, w której zawarte są normy kompetencyjne dla administracji morskiej.

Kolejną zmiana, która ma wpływ na zakres podmiotowy stosowania ustawy o bezpieczeństwie morskim, są przepisy dotyczące jachtów. W słowniczku u.b.m., zawartym w art. 5, zmieniono pkt 7 definiujący jacht. Zmiana prowadzi do objęcia zakresem ustawy wszystkich jachtów rekreacyjnych i komercyjnych bez względu na rodzaj napędu ${ }^{22}$.

Legislator, podsumowując blisko trzyletni okres działania przepisów ustawy, uznał, że usprawnienia wymaga funkcjonowanie przepisów dotyczących inspekcji państwa bandery, m.in. w stosunku do jachtów. $Z$ prowadzonych zmian wynika, że armatorzy jachtów rekreacyjnych i sportowych mogą opracować dla tych jednostek kartę bezpieczeństwa, co w zamyśle powodować ma, iż działania inspekcyjne będą mniej uciążliwe i sprowadzą się do weryfikacji zapisów karty. Środowisko żeglarskie nie przyjęło proponowanej zmiany z entuzjazmem, uznając to za nałożenie dodatkowych obciążeń. Jednak całościowa analiza wprowadzonych zmian prowadzi do wniosku, że w stosunku do stanu poprzednio obowiązującego karta bezpieczeństwa stanowić może ułatwienie dla żeglarzy. Akty wykonawcze opracowane dla ustawy nie zmieniają bowiem zasad inspekcji, jakim podlegają jachty. Jachty morskie poniżej $15 \mathrm{~m}$ długości, identycznie jak dotąd, nie będą zatem poddane obowiązkowi inspekcyjnemu. Natomiast sama instrukcja bezpieczeństwa stanowi w pewnym sensie wyraz dalszej liberalizacji,

morskiego, tym bardziej że stworzenie tego typu rejestru będzie konieczne na mocy dyrektywy 2013/30/UE.

${ }^{21}$ Dz.U. Nr 32, poz. 131.

${ }^{22} \mathrm{~W}$ obecnie obowiązującym brzmieniu ustawa dotyczy jachtów komercyjnych lub rekreacyjnych o napędzie żaglowym lub mechanicznym. Wprowadzono także definicje długości statku i jachtu morskiego, zaczerpnięte z konwencji SOLAS. 
zakłada bowiem, że armatorzy jachtów, które muszą na mocy ustawy być poddane inspekcji państwa bandery, mogą uwolnić się od tego obowiązku przez opracowanie karty bezpieczeństwa zatwierdzanej przez właściwego dyrektora urzędu morskiego. Nie jest to liberalizacja w takim zakresie, jakiego oczekiwało środowisko żeglarskie. Trudno jednak zgodzić się z tezą środowiska jachtowego, że cofa ona liberalizację sprzed ośmiu lat, kiedy to zmieniono przepisy dotyczące jachtów komercyjnych. Natomiast dobrym rozwiązaniem, jak się wydaje, byłoby zapisanie $\mathrm{w}$ akcie rangi ustawy zwolnienia jachtów rekreacyjnych o długości do $15 \mathrm{~m} \mathrm{z}$ obowiązku poddania się inspekcjom. Skoro jednym z celów nowelizacji było uregulowanie na poziomie ustawy kwestii dotyczących inspekcji jachtów morskich, to także kwestię zwolnienia tej kategorii jachtów można było w ustawie określić. Zapewne dawałoby to środowiskom żeglarskim większą pewność niż zapisy w rozporządzeniach wykonawczych w zakresie liberalizacji przepisów wprowadzonej kilka lat temu. Podsumowując, przyjęte rozwiązanie wydaje się prowadzić do zmniejszenia obciążeń biurokratycznych, które dotykają armatorów jachtów. Nie ma w tej materii możliwości oceny polskiej regulacji w zakresie jej zgodności z regulacją międzynarodowa, bowiem nie istnieją jednolite konwencyjne normy inspekcyjne dotyczące jachtów i dokumentów wydawanych armatorom jachtów. Kwestie te nie są uregulowane także w przepisach unijnych.

Ponadto na mocy znowelizowanych przepisów możliwe jest wydawanie zwolnień dla jachtów w zakresie wyposażenia i konstrukcji. Wprowadzenie do prawa polskiego przepisu umożliwiającego stosowanie zwolnień lub środków równoważnych w stosunku do jachtów pozwala na bardziej elastyczne podejście do wymogów dotyczących konkretnych jednostek ${ }^{23}$.

Pozostając przy tematyce jachtów, w ustawie zapisano obowiązek posiadania ubezpieczenia odpowiedzialności cywilnej dla podmiotów

${ }^{23}$ Proponowane zmiany do art. 110 u.b.m. mają na celu doprecyzowanie obowiązującego przepisu i jednoznaczne wskazanie, że wymaganie nie dotyczy ubezpieczenia określonego w Kodeksie morskim, a związanego z ubezpieczeniem pasażerów zgodnie z postanowieniami Konwencji ateńskiej z dnia 13 XII 1974 r. w sprawie przewozu morzem pasażerów i ich bagażu (Dz.U. 1987 Nr 18, poz. 108). Proponowana zmiana ma na celu umożliwienie dyrektorom urzędów morskich wydawania zwolnień lub zastosowania środków równoważnych dla jachtów morskich, w zakresie ograniczonym jedynie do konstrukcji i wyposażenia statku, dla statków, które ze szczególnych i indywidualnych powodów, np. ze względu na nietypową konstrukcję, nie są w stanie takich wymagań spełnić. 
przeprowadzających przeglądy jachtów komercyjnych. Zmiana ta wynika $\mathrm{z}$ uznania tego ubezpieczenia za obowiązkowe $\mathrm{w}$ rozumieniu ustawy o ubezpieczeniach obowiązkowych i których regulacja musi mieć umocowanie ustawowe ${ }^{24}$.

\subsection{Problem instytucji klasyfikacyjnych}

Zmiana, która nie została wyeksponowana w dokumentacji procesu legislacyjnego, jest wprowadzenie ustawą o bezpieczeństwie morskim przywoływanej już dyrektywy unijnej 2014/111/UE, a jest to zmiana niezwykle istotna dla polskiej instytucji klasyfikacyjnej. Instytucje klasyfikacyjne są to przedsiębiorstwa, najczęściej prywatne, zajmujące się klasyfikacją statków, takie jak np. Lloyd's Register of Shipping czy Polski Rejestr Statków ${ }^{25}$. Na mocy decyzji właściwego organu krajowego powierzone mogą być im pewne kompetencje administracji publicznej ${ }^{26}$.W Polsce takim podmiotem jest Polski Rejestr Statków. Kwestie te uregulowane są w prawie międzynarodowym w kodeksach Międzynarodowej Organizacji Morskiej. Dyrektywa Unii Europejskiej 2014/111 zmienia jednak postanowienia dwóch kodeksów IMO: kodeksu dla uznanych organizacji ( $R O$ Code) i kodeksu wdrażania instrumentów IMO (III Code) w zakresie uznawania instytucji klasyfikacyjnych. Z prawa unijnego wynika mniejsza w stosunku do regulacji IMO decyzyjność państw. Na mocy dyrektywy mogą one bowiem przyznawać status instytucji klasyfikacyjnej tylko takim podmiotom, które zostały uznane przez Komisję Europejską. Rozbieżności między wymogami prawa UE a regulacjami międzynarodowymi prowadzą w efekcie do mniej korzystnej sytuacji uznanych przez UE towarzystw klasyfikacyjnych,

${ }^{24}$ Zgodnie z art. 22 ust. 2 Ustawy z dnia 22 V 2003 r. o ubezpieczeniach obowiązkowych, Ubezpieczeniowym Funduszu Gwarancyjnym i Polskim Biurze Ubezpieczycieli Komunikacyjnych (tekst jedn. Dz.U. 2016, poz. 2060). W kontekście obowiązków ubezpieczeniowych warto wskazać na rozszerzenie obowiązku posiadania ubezpieczenia odpowiedzialności cywilnej prowadzącego jacht oraz ubezpieczenia następstw nieszczęśliwych wypadków obejmującego wszystkie osoby znajdujące się na jachcie dla armatorów jachtów komercyjnych innych niż jachty komercyjne odpłatnie udostępniane bez załogi. Konsekwencją braku takiego ubezpieczenia jest możliwość nałożenia kary finansowej na armatora lub kapitana wspomnianych jachtów.

${ }^{25}$ Instytucje klasyfikacyjne są to pozarządowe instytucje oferujące usługi klasyfikacji statków, polegające na ocenie dokonywanej przez rzeczoznawców.

${ }^{26}$ Ocena ma wówczas taką samą moc jak ta dokonana przez państwo rejestru statku. 
w tym Polskiego Rejestru Statków, które zmuszone są na mocy regulacji UE do podniesienia wymogów wobec niespełniających standardów statków państw trzecich albo zaprzestania świadczenia dla nich usług. W konsekwencji oznaczać to może utratę armatorów statków państw niebędących stronami konwencji międzynarodowych z zakresu bezpieczeństwa morskiego, a będących obecnie klientami europejskich instytucji klasyfikacyjnych. Wydaje się, że straty finansowe będące konsekwencją wdrożenia wspomnianych postanowień są dla europejskich instytucji klasyfikacyjnych nie do uniknięcia. Przyjęcie jednak takiej regulacji niewątpliwie podnosi poziom bezpieczeństwa morskiego, a legislacja unijna zwiększająca nadzór państw nad działalnością instytucji klasyfikacyjnych prowadzi w efekcie do zwiększenia nadzoru nad nimi także $\mathrm{w}$ prawie międzynarodowym.

\subsection{Zmiany w kompetencjach terenowych organów administracji morskiej}

W noweli doprecyzowano system nadzoru stacji atestacji urządzeń i wyposażenia morskiego. Obowiązek sprawowania nadzoru przez polską administrację morską nad stacjami atestacji wynika z konieczności zapewnienia, aby obsługa, naprawa i atestacja urządzeń oraz wyposażenia statku pływającego pod polską banderą były przeprowadzane zgodnie z wymogami ustanowionymi przez IMO w konwencjach, których Polska jest stroną. System nadzoru stacji atestacji urządzeń i wyposażenia statków nie uległ właściwie zmianie. Nowością jest natomiast wprowadzenie podziału właściwości terytorialnej dyrektorów urzędów morskich w zakresie nadzoru nad wspomnianymi stacjami atestacji. Podział taki jest zawarty w ustawie o obszarach morskich i administracji morskiej, ale $z$ natury rzeczy nie dotyczy terytorium całego kraju, lecz jedynie obszarów podlegających terenowym organom administracji morskiej, a więc wybrzeża i polskich obszarów morskich. Stacje atestacji moga natomiast znajdować się w głębi kraju, poza zakresem terytorialnym wskazanym w ustawie o obszarach morskich i administracji morskiej, dlatego zasadne było określenie właściwości terytorialnej dyrektorów urzędów morskich w tym zakresie.

Zadania dyrektorów urzędów morskich związane z wykonywaniem zadań inspekcyjnych zostały rozbudowane także o kwestie dotyczące recyklingu statków. Nowelizacja uwzględnia regulację, do której 
wprowadzenia Polska zobowiązana była na mocy rozporządzenia unijnego $1257 / 2013^{27}$. Na Polsce ciąży obowiązek unormowania pewnych kwestii w zakresie nieuregulowanym w rozporządzeniu unijnym, w tym kwestii wyznaczenia organów odpowiedzialnych za bezpieczny recykling statków. Zgodnie z nowym artykułem 18a u.b.m. organami inspekcyjnymi w zakresie recyklingu statków są właściwi dyrektorzy urzędów morskich. Wydaje się jednak, że lepszym miejscem dla tej regulacji byłaby Ustawa z dnia 16 marca 1995 r. o zapobieganiu zanieczyszczeniu morza przez statki ${ }^{28}$, która reguluje materię związaną z ochroną środowiska morskiego.

Doprecyzowaniu uległy także postanowienia dotyczące obowiązków inspekcyjnych dyrektorów urzędów morskich. Zmiany do art. 20 u.b.m. umożliwiają uregulowanie w akcie wykonawczym zakresu odnoszących się do statków przepisów nieobjętych konwencjami międzynarodowymi, a więc tych, dla których zakres zwolnień nie jest uregulowany wprost w prawie międzynarodowym. Wprowadzona zmiana pozwala na zrównanie możliwości uzyskania zwolnienia przez statki konwencyjne i niekonwencyjne. Liberalizacji uległy ponadto przepisy dotyczące statków poniżej 24 m długości, które dotychczas w sytuacji przerejestrowania z obcego do polskiego rejestru podlegały takim samym obowiązkom administracyjnym jak duże statki. Wcześniejszy brak stosownej regulacji uznać można za niedopatrzenie, a stan wprowadzony nowelizacją - za trafne zmniejszenie obciążeń administracyjnych dla armatorów statków poniżej 24 m długości. Także w zakresie możliwości zwolnienia statku w odniesieniu do wymagań dotyczących wyposażenia i konstrukcji nowelizacja pozwala, poprzez wprowadzenie delegacji, na zliberalizowanie wymogów odnoszących się do statków nieobjętych postanowieniami konwencji międzynarodowych.

\subsection{Kwalifikacje załóg}

Znaczące zmiany zostały wprowadzone do przepisów rozdziału 4 u.b.m. dotyczącego składu i kwalifikacji załogi. Konieczność ich wprowadzenia wynika z przywoływanej już dyrektywy 2012/35/UE zmieniającej

${ }^{27}$ Rozporządzenie Parlamentu Europejskiego i Rady (UE) nr 1257/2013 z dnia 20 XI 2013 r. w sprawie recyklingu statków oraz zmieniające rozporządzenie (WE) nr 1013/2006 i dyrektywę 2009/16/WE (Dz.Urz. UE L 330 z 10 XII 2013 r., s. 1). Rozporządzenie to miało na celu zachęcenie państw członkowskich UE do ratyfikacji konwencji z Hong Kongu o bezpiecznym i przyjaznym dla środowiska recyklingu statków.

${ }^{28}$ Dz.U. Nr 47, poz. 243 ze zm. 
dyrektywę 2008/106/WE dotyczącą minimalnego poziomu wykształcenia marynarzy ${ }^{29}$.

Dyrektywa unijna wymaga, aby marynarze w państwach członkowskich byli wyszkoleni oraz posiadali dokumenty kwalifikacyjne zgodne $\mathrm{z}$ wymogami konwencji STCW. Nowelizacja zakłada szczegółowe uregulowanie tej kwestii w rozporządzeniu wykonawczym określającym warunki certyfikacji i przyznawania dokumentów kwalifikacyjnych członkom załóg statków morskich oraz uprawnienia wynikające $\mathrm{z}$ tych dokumentów ${ }^{30}$. Dyrektywa wymaga wskazania organu krajowego prowadzącego weryfikację ważności i autentyczności dokumentów. W ustawie wskazano jako organ właściwy dyrektora urzędu morskiego. Natomiast nadzór nad morskimi jednostkami edukacyjnymi (MJE) pozostaje kompetencją ministra właściwego do spraw gospodarki morskiej.

Model nadzoru nad MJE nie uległ zmianie. Morskimi jednostkami edukacyjnymi są uczelnie morskie wskazane w ustawie o szkolnictwie wyższym ${ }^{31}$, inne uczelnie, wydziały lub struktury międzywydziałowe uczelni oraz szkoły ponadgimnazjalne, placówki kształcenia praktycznego, dokształcania i doskonalenia zawodowego, uznane przez ministra właściwego do spraw gospodarki morskiej. Zapis taki, zawarty w art. 74 u.b.m., budzi wątpliwości dotyczące trybu i formy uznania. Wątpliwości tych nie rozwiewają postanowienia dodanych ustępów wskazujące jako podstawę uznania spełnienie przez MJE wymogów konwencji STCW oraz rejestracji szkoleń. Poprzednio obowiązujące brzmienie, zawierające zwrot "uznanie w drodze decyzji", nie budziło zastrzeżeń i trudno wskazać powody jego modyfikacji. Podobne wątpliwości dotyczą treści art. 75 u.b.m. Zgodnie z nim minister do spraw gospodarki morskiej uznaje oraz sprawuje nadzór nad morskimi jednostkami edukacyjnymi oraz uznanymi ośrodkami w zakresie szkolenia członków załóg statków morskich oraz zgodności z przepisami ustawy lub konwencji STCW, dokonując audytów. Z nowego brzmienia art. 76 u.b.m. wynika,

${ }^{29}$ A zatem z głównego aktu prawa UE wprowadzającego postanowienia konwencji STCW. Dyrektywa wymaga, aby w prawie krajowym określono sposoby zawierania umów o żegludze przybrzeżnej mogącej być wykonywaną przez statki państw UE bez konieczności spełniania wymogów dodatkowych, w stosunku do statków państwa wybrzeża.

${ }^{30} \mathrm{~W}$ stosunku do wcześniej obowiązującego rozporządzenia w sprawie wyszkolenia i kwalifikacji członków załóg statków morskich regulacja uzupełniona została o niektóre wzory zaświadczeń.

${ }^{31}$ Ustawa z dnia 27 VII 2005 r. Prawo o szkolnictwie wyższym (tekst jedn. Dz.U. 2016, poz. 1842). 
że w audycie tym brać będą udział eksperci i obserwatorzy, ale - ponownie - nie przewidziano trybu i formy ich wskazania. Wydaje się, że stanem bardziej pożądanym, dającym większą pewność, byłoby uregulowanie obu wspomnianych elementów materią ustawowa, a jedynie doprecyzowanie ich w rozporządzeniach.

Zmiany w zakresie modelu sprawowania nadzoru nad MJE poprzez system audytów wprowadzane są do polskiego prawa konsekwentnie i zmierzają do centralizacji systemu egzaminowania. Ostatnia nowelizacja w sposób znaczący porządkuje i doprecyzowuje praktyczne elementy dokonywania audytów, takie jak np. kwestie wynagrodzeń członków zespołu przeprowadzającego audyt. Nieco istotniejszą zmiana, czyniącą system bardziej elastycznym, jest wprowadzenie możliwości udziału w audytach morskich jednostek edukacyjnych ekspertów niespełniających wszystkich wymagań, jakie są nakładane na audytorów MJE, ale których wiedza ekspercka może być przydatna lub niezbędna do właściwego przeprowadzenia audytu. Wprowadzono także możliwość prowadzenia szkoleń dla pracowników gospodarki morskiej innych niż marynarze. Zmiany w zakresie funkcjonowania MJE jednoznacznie zmierzają do zapewnienia stosowania jednolitego standardu prowadzenia szkoleń, przeszkoleń i egzaminów praktycznych, ograniczając autonomię uczelni morskich w tym zakresie.

Przyjęte w art. 78 ust. 2 u.b.m. rozwiązania dotyczące ustalania w rozporządzeniach wykonawczych ramowych programów dodatkowych szkoleń i szczegółowych warunków wstępnych dla osób związanych z gospodarką morską wydają się zbyt mało stabilne z perspektywy osób zainteresowanych takim szkoleniem. Być może warto byłoby raczej rozważyć odesłanie do prawa międzynarodowego, które ulega w tym zakresie częstym zmianom, albo określenie warunków wstępnych w ustawie. Zapewniałoby to większą pewność osobom, które decydują się na te szkolenia. Podobnie ma się sytuacja z wymogami wobec członków Centralnej Morskiej Komisji Egzaminacyjnej (CMKE). Kryteria, jakie muszą spełniać kandydaci na członków tego gremium, określane były dotąd w rozporządzeniu, co należy uznać za niezgodne z zasadami techniki prawodawczej, gdyż kryteria wstępne, stanowiące materialną podstawę uznania kwalifikacji członków CMKE, powinny być, jak się wydaje, regulowane w sposób ustawowy. Nowelizacja była dobrą okazją do uporządkowania i tej kwestii. Niestety, dokonano jedynie kosmetycznej zmiany, słowo „kryteria” zastępując pojęciem "Warunki". 
Zmiany dotyczące kwalifikacji załóg mają charakter porządkujący, doprecyzowujący. Regulacja wprowadza także możliwość uznawania przez dyrektora urzędu morskiego kwalifikacji niezbędnych do uzyskania dyplomów lub świadectw oficerskich na podstawie praktyki. Poprawka ta wydaje się słuszna, biorąc pod uwagę, że żegluga zmienia się bardzo szybko i uznanie dyrektora urzędu morskiego pozwala na elastyczniejsze reagowanie na te przeobrażenia niż ustawa. Szkoda, że podobnego mechanizmu nie zastosowano w odniesieniu do wymogów stawianych członkom CMKE.

Dodatkowo w nowelizacji podjęto próbę uporządkowania i rozwiązania trudności, które unaoczniły się od momentu wejścia w życie nowej ustawy o bezpieczeństwie morskim w związku z samym funkcjonowaniem CMKE oraz wydawaniem dokumentów kwalifikacyjnych marynarzy. Brak stosownych regulacji właściwie paraliżował pracę CMKE. Potrzebne było przyjęcie zasad nawiązywania stosunku pracy członków tej komisji, ich wynagradzania, podziału obowiązków administracyjnych i technicznych związanych z jej obsługą między ministra właściwego do spraw gospodarki morskiej i dyrektorów urzędów morskich. Nowelizacja unormowała kwestie formy organizacyjnej i zasad budżetowania CMKE, rozwiewając niejasności w tym zakresie. Ponadto uregulowano kwestię związaną z zapewnieniem nadzoru ministra gospodarki morskiej nad systemem kształcenia kadr morskich poprzez wskazanie konieczności udziału członka CMKE w egzaminach na uczelniach morskich. Nowelizacja rozszerza także kompetencje ministra właściwego do spraw gospodarki morskiej o utworzenie i zatwierdzenie banku pytań egzaminacyjnych. Regulacja ta służyć ma ujednoliceniu kryteriów egzaminacyjnych. Całość zmian jednoznacznie potwierdza przyjęcie przez ustawodawcę koncepcji centralizacji szkoleń marynarzy.

\subsection{Bezpieczne uprawianie żeglugi}

Nowela wprowadza możliwość zastosowania środków równoważnych do wymogów ustawowych dotyczących wyposażenia i konstrukcji statku w przypadkach, gdy cechy konstrukcyjne statku albo rejon lub warunki żeglugi nie pozwalają na zastosowanie przepisów szczegółowych wydanych na podstawie art. 86 ust. 3 u.b.m. Stosowna decyzja w tym zakresie wydawana będzie przez właściwego dyrektora urzędu 
na wniosek armatora. Dyrektor urzędu morskiego może także zwolnić statek z obowiązku stosowania szczegółowych warunków bezpiecznej żeglugi. Przesłanką wydania pozytywnej dla armatora decyzji w obu sytuacjach jest zapewnienie zastosowania takich środków, które nie będą prowadziły do zmniejszenia poziomu bezpieczeństwa żeglugi. Zwolnienie takie dotyczyć może jedynie kwestii wyposażenia i konstrukcji statku. Jest to zmiana, która - jak się wydaje - będzie miała zastosowanie w wyjątkowych, rzadkich przypadkach. Należy natomiast wskazać słuszność przyjętego rozwiązania, które pozwala na bardziej praktyczne niż "papierowe” podejście do sytuacji, w których armatorzy statków nietypowych nie byliby w stanie ich eksploatować, gdyby obowiązywały ich sztywne przepisy.

Wypełniając dyrektywy unijne, ustawa zmienia ponadto zakres opracowywania i przekazywania na poziom UE danych statystycznych związanych z wydawaniem przez Polskę dyplomów kwalifikacyjnych i potwierdzeń uznania zagranicznych dyplomów lub świadectw oraz wprowadza wyczekiwane od dawna przez środowisko prawników morskich zmiany dotyczące pilotażu morskiego w zakresie dotyczącym uregulowania w samej ustawie kwestii tak istotnych jak to, kto prowadzi szkolenia pilotów, a także odnoszących się do zatwierdzania przez administrację państwową programów szkoleń pilotów i przeprowadzania audytów szkoleń czy organizacji stacji pilotowych. Zmiany dotknęły również służb ratowniczych (SAR), zmierzając zasadniczo do wzmocnienia Rady SAR przy ministrze właściwym do spraw gospodarki morskiej. Drobne zmiany wprowadzono także w zakresie sankcji nakładanych na mocy u.b.m. Ponadto ustawa zmienia przepisy Kodeksu morskiego ${ }^{32}$ oraz ustawy o ochronie żeglugi i portów morskich $^{33}$.

Warto ponadto zwrócić uwagę na zmiany w ustawie o Państwowej Komisji Badania Wypadków Morskich (PKBWM) ${ }^{34}$ wprowadzające nowe znaczenie pojęcia wypadku morskiego w polskim prawie. Należy jednak rozważyć kwestię rozszerzenia kompetencji tej komisji na

\footnotetext{
${ }^{32}$ Głównie dotyczące pilotażu oraz pojęcia stałej platformy wiertniczej.

${ }^{33}$ Główne założenia mają na celu objęcie stałych platform wiertniczych postanowieniami kodeksów ISM i ISPS (Międzynarodowy Kodeks Ochrony Statku i Obiektu Portowego).

${ }^{34}$ Ustawa z dnia 31 VIII 2012 r. o Państwowej Komisji Badania Wypadków Morskich (Dz.U. poz. 1068).
} 
wypadki mające miejsce na stałych platformach wiertniczych, skoro pojęcie to zostało włączone do ustawy o bezpieczeństwie morskim.

Zredukowano także obowiązek przekazywania izbom morskim materiałów dotyczących wypadków do sytuacji, gdy takich dokumentów zażąda sama izba. Ewidentnie istnienie tego obowiązku było niedopatrzeniem ustawodawcy i pozostałością stanu prawnego sprzed powołania PKBWM na mocy ustawy z 2012 r., kiedy to postanowiono, że izby morskie nie będą już orzekać z urzędu, ale jedynie na wniosek osoby zainteresowanej lub organu administracji morskiej.

\section{Podsumowanie}

Na podstawie przeprowadzonych rozważań należy stwierdzić, że nowelizacja ustawy o bezpieczeństwie morskim jest zasadna w kontekście zobowiązań, jakie wynikają dla Polski z prawa międzynarodowego i UE. Uwagi krytyczne dotyczą głównie zbyt szczegółowych czasem regulacji, co jest słabością polskiej legislacji we wszystkich tych materiach, które regulowane są na styku zobowiązań wynikających z prawa międzynarodowego i prawa unijnego, wprowadzającego często pewne odstępstwa od regulacji międzynarodowych.

Zmiany, które wprowadzone zostały omawiana, obszerną nowelizacją, w znaczącej mierze ilustrują niedoskonałość samej ustawy. Wiele poprawek dokonywanych było również przy okazji nowelizacji innych ustaw, a ich liczba jest ogromna. Zmiany te w znaczącej części doprecyzowują i niwelują niedoskonałości starej ustawy (są to zmiany głównie dotyczące funkcjonowania CMKE czy organizacji pilotażu), a były bardzo potrzebne, aby pewne instytucje ustawy mogły właściwie funkcjonować. Drugi element wiąże się z koniecznością wprowadzenia do polskiego prawa zmian wynikających z zewnętrznych źródeł: prawa międzynarodowego i prawa UE. Także te zmiany finalnie należy ocenić jako potrzebne. Trudno jednak nie dostrzegać braku szerszej perspektywy związanej z wdrażaniem do prawa polskiego zmian wynikających z konwencji międzynarodowych i prawa UE. Nie jest to zarzut pod adresem legislacji morskiej, ale legislacji polskiej w ogóle, w której nakładają się powinności wynikające $\mathrm{z}$ prawa międzynarodowego i prawa unijnego. Ogrom pracy urzędników, którzy dbają o terminowe wdrożenie regulacji unijnych bardzo często prowadzi do nakładania się 
tychże regulacji, powstawania niejasności czy nieuchwycenia istoty rzeczy w normie prawnej ${ }^{35}$. Najbardziej wyrazistym elementem przyjętych zmian jest rosnąca centralizacja i formalizacja sposobu nadzorowania przez państwo bezpieczeństwa morskiego. Istnieje niewiele przepisów pozwalających na elastyczne podejście do pojawiających się problemów. Większość kwestii poddana jest szczegółowym procedurom pisemnym oraz centralnemu zarządzaniu i decyzyjności. Omawiana nowelizacja zdecydowanie umacnia ów sposób zarządzania bezpieczeństwem, czego przejawem jest dalsze zwiększanie roli Centralnej Morskiej Komisji Egzaminacyjnej oraz nadzoru nad morskimi jednostkami edukacyjnymi, co zmierza do ujednolicenia standardów kształcenia i egzaminowania. Jest to wyraz przyjętej przed laty koncepcji bezpieczeństwa morskiego, z którą można polemizować; trzeba wszakże przyznać, że konsekwencja ustawodawcy w tym zakresie jest wyraźna także w przepisach nowelizacji. Docenić jednak należy pewną elastyczność wprowadzoną w odniesieniu do armatorów statków małych lub nietypowych, związaną np. z kartą bezpieczeństwa dla jachtów czy zakresem uznaniowości przyznanym organom, dyrektorom urzędów morskich we wspomnianym wyżej zakresie stosowania środków równoważnych do wymogów ustawowych.

Mnogość przepisów międzynarodowych i unijnych w zakresie bezpieczeństwa morskiego powinna skłaniać do rozważenia uregulowania wszystkich aspektów bezpieczeństwa morskiego w jednym, kompleksowym akcie prawnym - prawie bezpieczeństwa morskiego. Prace nad sugerowaną ustawą wymagałyby systemowej analizy materii bezpieczeństwa morskiego zarówno w ujęciu safety, jak i security.

\section{DIRECTIONS OF CHANGES IN POLISH MARITIME SAFETY LAW}

\section{S u m m a ry}

The article tackles the issue of amendments to Polish maritime safety law which has been amended a number of times since it came to life several years ago. The last amendments of 2015 have been the most profound and complex.

Today, maritime safety is given much more importance than several dozen years ago. The public and private aspects of maritime safety became the focus of attention rather recently but are now a branch of law that is developing the most

${ }^{35}$ Dotyczy to np. wprowadzenia pojęcia miejsc schronienia w ustawie o bezpieczeństwie morskim z 2011 r., które nie oddaje istoty koncepcji place of refuge. 
dynamically. As has been shown in the paper, although private maritime law was already known in the Ancient Times, public-private law regulations were adopted only after the sinking of the Titanic in 1912. Still, it is not the private but the public aspects of maritime safety law which constitutes the major challenge. The abundance of international and European legislation ought to prompt the Polish legislator to consider a possible adoption of one comprehensive maritime safety act which would approach the whole matter in question in a systematic manner. The deliberations presented in the paper sum up the amendments to maritime safety law made so far. They are also an attempt to analyse the new legal order more deeply, and propose some more general de lege ferenda conclusions. The analysis is set in a wider context, taking into account the amendments introduced to international and EU regulations.

Keywords: maritime safety - maritime administration - ISM code - international maritime conventions - the SOLAS convention 